\title{
大阪の発展と土地会社の功績
}

\section{1. 大阪の人口増加}

大阪の人口の初見は、慶安 4 年 (1651) の 188,001 人 である。大阪落城は元和 1 年 (1615)であつたから、36年 目の復興振りに当る。当時の大阪の区域は秀吉時代の船 場、島の内、天満の外飞、下船場、上町が新た開かれ 始めているから、人口密度は必ずしも多い方ではない。

それからは年々遁増して、元文 4 年 (1739)飞は400,000 人を突破することになる。そして文化の華やかであつた 明和 2 年 (1765) が 419,863 人で、幕府時代を逆じての 最高であつた。

これ等の人口には武士僧侣非人等は加算されない慣は しであつたから、大阪の実際の人口は、これ等の数の 1 割増し位と考えてよい。そうすると江戸の約半分であつ to

然し乍らその後僅から゙つ減少した。乞うして天保年間 《は城代が特別の繁栄策を講じなければならない程、人 口が減じ町が不景気になつた。それでも何、人口は減少 の一途を辿つて、明治 1 年 (1867) そは 281,306 人とな り、更に維新で藩政の廃止から、各藩を相手の大阪商人 恃大打撃を受けて、終江明治 5 年汇は 259,986 人と最盛 時から見ると、4 割に及ぶ減少となつて、これが最低の 記録であつた。

その後明治政府の成功は民力を大いに暢脹さすととに なつて、大阪の人口は再び膨脹を始めた。即ち明治 15 年は 332,425 人飞明治 22 年は 472,247 人になつた。即 ち市制が施行された明治 22 年には既に徳川時代の最高 を突破することにならた。

日清戦争直後からは資本主義挃頭によつて、大阪の人 口増加に泊車加掛つて、明治 30 年 758,285 人に、明 治 35 年 951,031 人飞、明治 40 年 $1,117,193$ 人飞、大 正 1 年 $1,330,709$ 人に、大正 6 年 $1,556,377$ となつた。

其後引続いての增加が、今日の大阪を形成している。

\section{2. 人口增加之都市区域の膨脹}

徳川時代の中葉から人口が減少し始めたとはい方、そ の為に都市区域が縮少するということは無かつた。それ で明治 22 年の人口は徳川時代の最高数を突破したが、 この程度では人口密度が大になつた位で、区域が膨脹す る所まで至つていない。

日清戦争後の急激な人口増加は䅂に日露戦争直前には 徳川時代の最高の倍に達せしめた。今度従前の区域で は入り切れなくなつて膨脹するととになる。

\footnotetext{
* 大阪工業大学教授 工学博士
}

\section{正会員 王 置 豊 次 郎*}

由来大阪の周辺は歴史的に文化が最も早く開けた地方 である。従つて昔から高きは削り低きは埋めて、土地は 出来るだけこれを田とした。それで大渡の区域は灌涀不 能の上町高台を除いて、田で囲繞されていた。この場合 都市区域が拡張されることになると、必然的に群村形式 をとることになり、武蔵野のよろ亿散村的に人家が散発 することは無い。それで大阪の区域の膨脹には土地の埋 立が先行しなければならなかつ。この埋立の土を得る ことが及容易でなかつた為に、僅かね゙かりの埋立てた土 地出来るだけ家を多く建てようとした。偶々に大阪は 天領であつた為に、他の城下町に見るような広大な武家 屋敷地が無く、町全体が緑を忘れた殺風景なるのであつ た。それ故洞囲の田甫を埋立て、空地るなく目白押し 汇矮小な家屋が建ち並んです、特汇異としなかつた。

一方德川時代には人口増加に先き達つて、必ず市街地 が造成されて和り、田甫の畦道の儘で家が建て連らねら れることは無かつた。然るに明治政府は都市膨膔に関す る限り全く無関心であつた為に、この時期に膨脹した区 域は乱雑その物であつて、正济都市計画史上の暗黒時代 であつた。急激に増加した大人口は悉くこの区域収容 されるより外なく、而も総ての不良住宅はこの地域に発 生した。

当時都市交通機関はまだ末発達であつたので、僅に上 町と天下茶屋が富豪の别荘地带であつて、その他は不良 住宅と隣同志の殺風景極をる乱雑な周辺部を急速们拥し 広げるのであつた。而してての面積恃龙大であつた。

\section{3. 土地会社の出現}

昔から役所以外では、従業員は店に住込みであった が、資本主義浸透と共飞様相が漸次変つて、事業場と住 宅が分離されることになり、サラリーマンが每日通勤す ることになつた。この場合大阪では他の都市と異なつて 武家屋敷地の置土産が無いので、これ等サラリーマンの 適当な住宅地が全然無かつた。これ等の人タはインテリ を自認しているので、矮小乱雑なスラム同然の周辺部は 勿論嫌墨した。

この重大な不満を経済人は素早く見抜いて、理想的な 住宅地の供給を思い立ち、土地会社を創設することにし た。居住者に喜んで貴うと同時に自分達も一と儲けしょ うとしたのであつた。

この土地会社の計画は田畑を堎平して、格子型に道路 を築造し、50〜100 坪の宅地を造成するのである。然し 乍ら当時としては、この団地だけは鶴が下りたようと良 
く見光たので、忽ちにして売り尽した。

この好売行を見て俄か炕土地会社の計画が随所飞企画 されることとなつた。

当時偶々ニューヨークの郊外で土地会社熱が大変昂揚 されていた。その数も相当多く経営地の面積も拡大であ つた。大阪での土地会社の隆盛は必ずしもアメリカに刺 戟された様子もないから、偶然時期が一致したものと見 做すべきでめろう。

都市計画的に晃て、この大阪の土地会社の盛行は、定 そ刮目して観るべきであつて、突如として勃興した土地 会社はその数多く経営地々当時としては相当の面積であ つた。表Iは大正 10 年 4 月現在の状況であるが、都市 計画暗黒時代飞宛も蒙味な政府を㗅笑するかの如く莫大 な資本と求大な地積が民間の手で都市計画的に処理され ていたことは、絶称されてよい。

表に示した通り大阪市内（太平洋戦争当時の市の行政 区域内）の土地会社は大正 7.8の両年に設立されたもの が多い。

この頃大阪の郊外電鉄の主要なるのは一応出揃つた。 これ等の電鉄の沿線とは、市に直接した周辺よりも良い 住宅候補地が多い。そこで土地会社は郊外電鉄の沿線兄 も進出することになつた。それまで郊外電鉄は商用か 物見遊山が主で、高い賃金を毎日払つて通勤用港ると いうことは、まだ考光られていなからた。然し乍らこの 時の郊外進出は定に目覚しいものがあつた。表Iは同じ く大正 10 年 4 月現在の状洗であるが、土地会社の設立 は市内よりも 1 年幄れて、大正 8,9 の両年が最子盛九

\begin{tabular}{|c|c|c|c|}
\hline \multirow{3}{*}{$\begin{array}{l}\quad 1 \\
\text { 土地会社名 } \\
\text { 大限咕港 }\end{array}$} & \multicolumn{3}{|c|}{ 大䛀市内土地会社維営地分布 } \\
\hline & \multirow[b]{2}{*}{ 設立年问 } & \multicolumn{2}{|c|}{ 大正10年4日現在 } \\
\hline & & 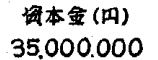 & $\begin{array}{l}\text { 経営地幅 (十市) } \\
823.978\end{array}$ \\
\hline 市田 & K. 56. & 4.300 .000 & 135.144 \\
\hline 安治川 & 大. 6.12 & 25.000 .000 & 506.202 \\
\hline 市田沿岸 & 大. 8.9 & 8.000 .000 & 18.448 \\
\hline 泉星 & 8月. 36.12 & 5.000 .000 & 250.265 \\
\hline 大阪港 & 9月 45.5 . & 5.000 .000 & 85.234 \\
\hline 木津川 & 大. 6.4. & 1.000 .000 & 21.200 \\
\hline 木冿川速场 & 大. 89 & 10.000 .000 & 175.145 \\
\hline 南大汲 & 大. 511. & 500.000 & 117.334 \\
\hline 四”揞 & 大 7.8. & 300.000 & 499 \\
\hline 大吸干日前 & 大.8.7. & 2.000 .000 & 2.000 \\
\hline $\begin{array}{l}\text { 日 } \\
\text { 限 }\end{array}$ & $\begin{array}{l}\text { ᄎ. } 2,4 . \\
\text { 明 } 44.7 .\end{array}$ & $\begin{array}{l}5.000 .000 \\
3.000000\end{array}$ & 1.324 \\
\hline 南 & 大. 5.8. & 3.000 .000 & 22.630 \\
\hline 大陙天王素 & 大. 8.8 & 1.0 .00 .000 & 49.671 \\
\hline 大险任容経営 & 大. 9.3. & 10.000 .000 & 15.000 \\
\hline 南 & ᄎ. 7.8 & 1.000 .000 & 6.680 \\
\hline 萧 & ᄎ. 7.10 & 10000.000 & 289.231 \\
\hline 東 & t. 7.10 & 6.000 .000 & 184.481 \\
\hline 螨 & ᄎ. 7.3 & $2.000,000$ & 23.301 \\
\hline tt & ᄎ. 8.5. & 3.000 .000 & 323.291 \\
\hline 津 & 明.45.6. & 3500.000 & 334.291 \\
\hline 大阪野江 & t. 8.12 & 2.500 .000 & 22.465 \\
\hline 果 & 大 9.4 & 10.000 .000 & 100.000 \\
\hline 北 大限 & $\pi 6.3$. & 2.000 .000 & 93.473 \\
\hline 神 & 大 7.4. & 1.400 .000 & 44.535 \\
\hline 浪速。 & 뼈 45.4 & 2.425 .000 & 178.954 \\
\hline
\end{tabular}

であつた。これ等の土地会社はイギリスの田園都市思潮 を採り入れて、大いに宣伝に用いた。スラム的周辺部に 愛想をつかした市民は田園都市という言葉に非常な魅力 を党えたのは当然と称すべきであろう。

大正 10 年 4 月現在では殆んぞの会社は、未だ設立後 両三年を出ないから、当時の考課表では欠損或は繰越が 多いようであつて、古参の会社だけが 1 割以上の配当を していたようである。然し乍ら経済界での土地会社株は

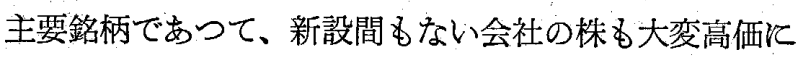
取引されていた。

大阪でのこの好評は僬て東京の伝え知る所となり、東 京に於ても土地会社が追々設立されるようとなつた。然 し乍ら総じて 3〜4 年晴れたようである。

\section{4. 土地会社の第二期}

前記の土地会社の経営には 3 つ形態があつた。

\begin{tabular}{|c|c|c|c|}
\hline 表 II & & 大阪近㢺土地会社程営地分布 & 10 年 4 月现在 \\
\hline 地地 & 驾年月 & 设本金 (用) & 经学地䅧(坪) \\
\hline 阪神住宅 & 大. 9. 3. & 10.000 .000 & 44,826 \\
\hline 尼崎城内 & 大. 8.11 . & 1.500 .000 & 9.681 \\
\hline 大神中央 & 大. 7.3. & 4.000 .000 & 111.470 \\
\hline 崎 & 大. 8.7. & 5.000 .000 & 11.464 \\
\hline 限急 & & & \\
\hline 宝 & 大.8.11. & $5.000,000$ & 600,000 \\
\hline ラヂウム & 大. 9.8. & 2.000 .000 & 67.408 \\
\hline 楼 & $\begin{array}{l}\star \\
\pi \quad 7.3 . \\
\end{array}$ & 1.500000 & $\begin{array}{r}23.000 \\
222611\end{array}$ \\
\hline $\begin{array}{l}\text { 甲 } \\
\text { 市 }\end{array}$ & $\begin{array}{r}\text { X.7. } 5 . \\
+\quad 9\end{array}$ & 2.500 .000 & 322.011 \\
\hline 市 & 大. 9.1. & 10.000 .000 & 789.580 \\
\hline in & 大. 9.3. & 2500.000 & 100.000 \\
\hline 芦 & 大. 7.10. & $1.000,000$ & 29.035 \\
\hline 大阪郎外 & 大. 8.12 & 4.000 .000 & 130.000 \\
\hline 檑 & 大. 8.6 & 1.200 .000 & 25.928 \\
\hline 花屡毀 & 大. 6.10 . & 1.600 .000 & 96.499 \\
\hline 新花尾数温臬 & К. 8.12 & 2.000 .000 & 5.10 .852 \\
\hline 晨 & 大. 811. & 3.000 .000 & 72888 \\
\hline 西 & 大 8.12 & 3.000 .000 & 50.340 \\
\hline 新京限 & & & \\
\hline (10) 大际任星柽 & 大.9.3 & 10.000000 & 130.000 \\
\hline 索磭 & & & \\
\hline 京 & 大. 8.11. & 5.000 .000 & 85.582 \\
\hline 帝国信託 & 大. 8.12 & 3000.000 & 71903 \\
\hline 日本家雷 & 大 8.6. & $2.000,000$ & 47.747 \\
\hline 许的 & & & \\
\hline 大阪土地遗河 & 大. 94. & 7.000 .000 & 1.02920 \\
\hline 大䡮 & & & \\
\hline 雪大吸 & 大. 5.11. & 1.000 .000 & 72.249 \\
\hline * & 大. 94. & 1.300 .000 & 130.000 \\
\hline 霜 & オ. 8. 5. & 4000000 & 75.041 \\
\hline 满 & ㅊ. 8.12 & 1.200000 & 40.000 \\
\hline te & 大. 8.11. & 1.000 .000 & 177.711 \\
\hline 日下温蚞 & 大. 9.1. & 1.500000 & 84990 \\
\hline 大生駇 & 大. 99 & 2.000000 & 183.363 \\
\hline 生弱中央 & ז. 9.1. & 1.000000 & 60000 \\
\hline 䥼 & 大. 8.9 & 1000000 & 16.000 \\
\hline 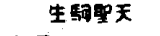 & 大 8.9. & 1.000 .000 & 66.000 \\
\hline 南海 & & & \\
\hline 洴 & ᄎ. 7.7 & 1.000000 & 31866. \\
\hline 倜大洪 & 大. 810 & 1.500000 & 16.670 \\
\hline $\begin{array}{l}\text { 北浜苐 } \\
\text { 日本工地 }\end{array}$ & $\begin{array}{r}\text { 大. } 86 \\
\text { 大. } 74\end{array}$ & $\begin{array}{l}1.000 .000 \\
2.000000\end{array}$ & $\begin{array}{l}24.620 \\
34.392\end{array}$ \\
\hline 南埧 & 大. 9.2 & 1.000000 & 14.676 \\
\hline 南＼cjkstart海 & 大. 8.5 & 1500.000 & 3.513 \\
\hline
\end{tabular}


1. 大阪湾臨海方面の新田の大地主が土地会社の組織 によつて、土地を開発し、その土地を分割賃貸するる の。この種のもので資力の特に優れたものは、住宅経営 をもしてその賃貸もする。

2. 地主が土地会社を設立して、所有地を分割売払え ばそれで仕事を終るもの。

3. 新らしい土地を買取つては区劃整理して分割譲渡 し、更に新らしい土地を売出すことを業とするるの。

1.は永久地主であるるから、会社は当然永続する。 3 .

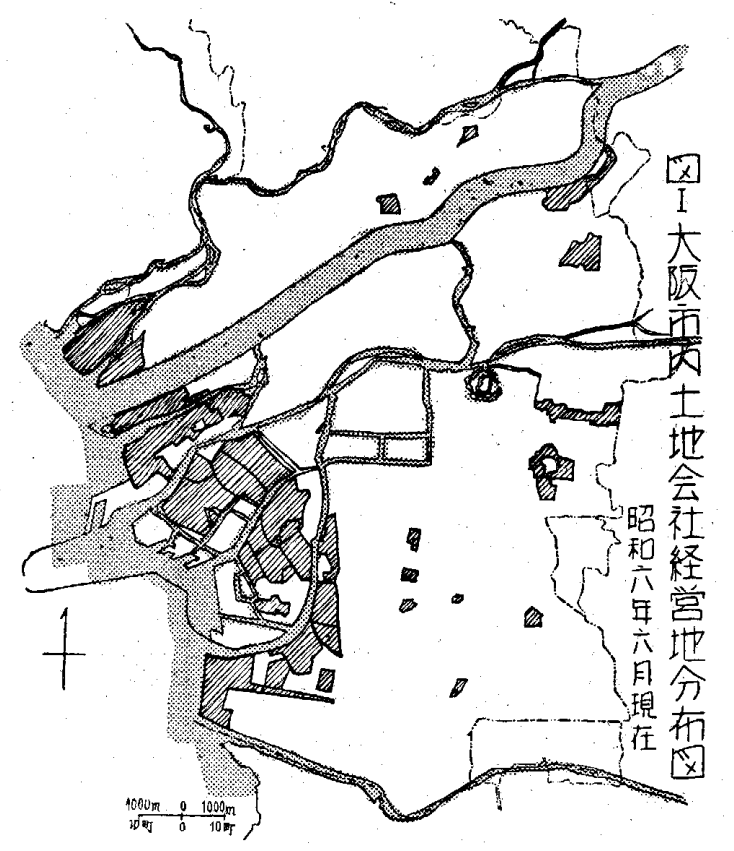

第 1 図

\begin{tabular}{|c|c|c|c|c|}
\hline & II & \multicolumn{3}{|c|}{ 大阪市内土地会社经觉地分布 } \\
\hline $\begin{array}{l}\text { 土地会 } \\
\text { 阿部三 }\end{array}$ & & 投立年月 & 谓本金 (四) & 柽学地皘 (㙕) \\
\hline $\begin{array}{l}\text { 政 } \\
\text { 大阪抽 }\end{array}$ & 成 & 明 40.11 & $\begin{array}{r}838,500 \\
35.000 .000\end{array}$ & $\begin{array}{l}110.000 \\
743.044\end{array}$ \\
\hline 售治 & & 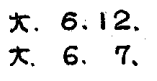 & $\begin{array}{r}25.000 .000 \\
1.000 .000\end{array}$ & $\begin{array}{r}487.114 \\
45.456\end{array}$ \\
\hline 外 & 材 & 大. 6. & $2.000,000$ & 87.500 \\
\hline 和 & 田 & 明, 40 . & 個 & 240.000 \\
\hline $\begin{array}{l}\text { के } \\
\text { 板 }\end{array}$ & 橉 & $\begin{array}{l}\text { 大. } 5.6 . \\
\text { 明. } 42 .\end{array}$ & $\begin{array}{c}4.300,000 \\
\wedge\end{array}$ & $\begin{array}{r}135.000 \\
42.000\end{array}$ \\
\hline 木津 & $m$ & 大. 6.4. & 1.000 .000 & 14.778 \\
\hline 和 & 2 & 大. 6. & 個 & 75.000 \\
\hline 4 & 血 & 明. 45,4 , & 2.000 .000 & 499.645 \\
\hline 大阪 & 港 & 明 45.5 . & 2.500 .000 & 94.000 \\
\hline 臬 & 尾 & 明.36.12. & 3.900 .000 & $\begin{array}{l}172.386 \\
(3.000\end{array}$ \\
\hline 宸 & 田 & 大 8.10. & 1.000 .000 & 146.527 \\
\hline 曰山秲 & & t.10. 3. & 10.000 .000 & 190.688 \\
\hline t & 阪 & 明. 448 . & $7,500.000$ & 24800 \\
\hline 离 & 津 & 大. 11.3. & 2000,000 & . \\
\hline 王 & 声 & 大. 8.8. & 1.000 .000 & 49.671 \\
\hline 新 大 & 阪 & 大.14. 5. & $10,000.000$ & 40.000 \\
\hline 今े & 里 & 大 14. & 3.600 .000 & 80.000 \\
\hline 城 & 東 & 大. 7.10. & 1.706 .250 & 289231 \\
\hline & 悤 & 大. 13.4. & $.100,000$ & 2990 \\
\hline 城 & 北 & 大. 8. & 3.000 .000 & 323.291 \\
\hline
\end{tabular}

も業者として残る。2.だけが消滅する。

斯くしてその後 10 年経過すると、大阪市内では 1 亿 該当するるのとして、新たに新罒の大地主で開発に乗り 出したすのが増加して来た。そして 2 に該当したものが 姿を消して行つた。表亚以昭和 6 年 6 月現在の状況であ る。

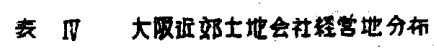

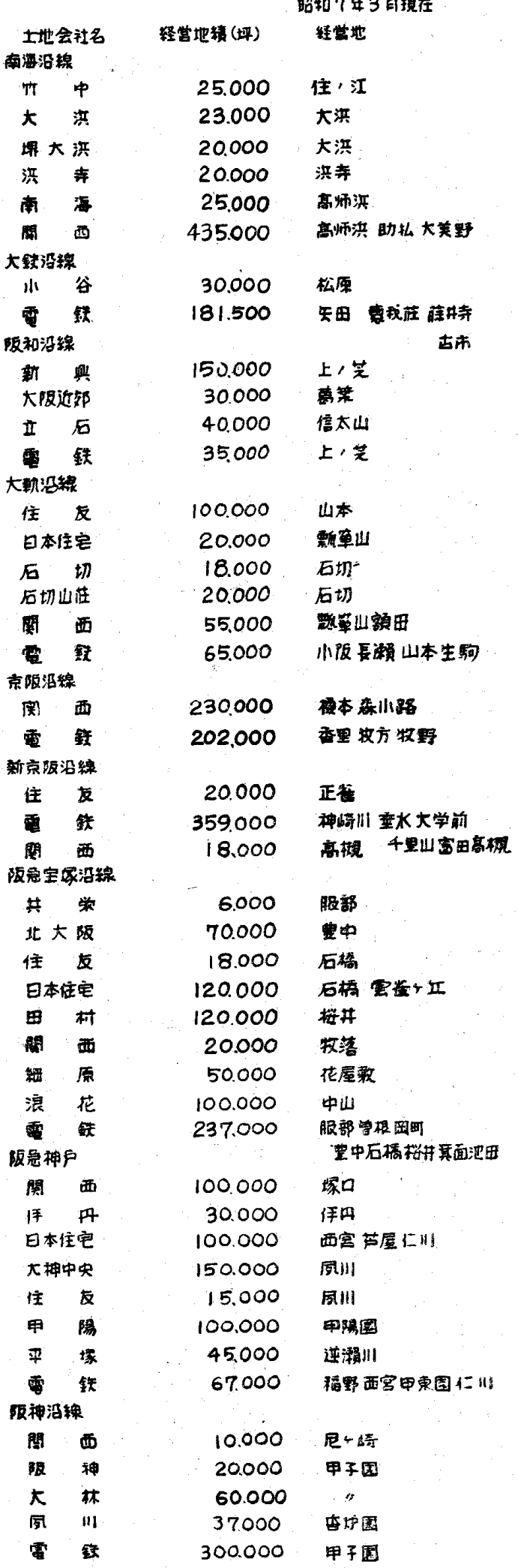


一方市内に比して、郊外では一層活発になって、経営 地も増加し、その面積も大となつてきた。結局郊外の環 境が需要者の意に叶つたからである。

この郊外での特徴は、初め沿線は電鉄会社とは別の土 地会社が手䯚けたのであつたが、今度は電鉄会社自らが 大規模に各社競争的に経営に乗り出したことである。云 ろまでもなく、好季節の遊山客や商用の乗客よりも、通 勤者の獲得の方が定期的で収入が確実であるから、住宅 地を出来るだけ增すことが必要であつた。多くの電鉄会 社では最初の数ケ月間の無貨乗車券を交付したりして、 土地購入者を釣つた。

資本的にも面積的にも、電鉄会社の経営地は、一般土 地会社の経営地には及ばなかつたが、殆んぞの電鉄会社 では、分譲地に理想的間取と銘した住宅を貄設して直ぐ 住めるようにし、而も庭も作り生垣を揃えたりしたこと が、一般の意響にマッチしたようである。

これ等の郊外地の経営状況は、表IVに示す通りであつ て、愈々昌んであつたことを知る。

\section{5. 区劃整理の進渉と土地会社の调落}

土地会社の盛行と併んで、大阪周辺部の農地の地主の 間で、耕地整理組合が結成されていた。これ等の組合の 中には純然たる耕地造成が目的のものもあつたが、宅地 造成の便乗組もあつた。組合の数及びその面積は、大正 14年 5 月 4 日現在で、12 組合 $3,745,738$ 坪であつて、 これ等のうち若干の組合地区の一部は、この時既々市街 地化していた。

然る所、都市計画法が施行されてからは、その区域内 では、当然土地区劃整理が耕地整理に代るべきであるが この話は当事者間で順調に進んだ。

そして大正 14 年頃から、区劃整理は軌道に乗ること

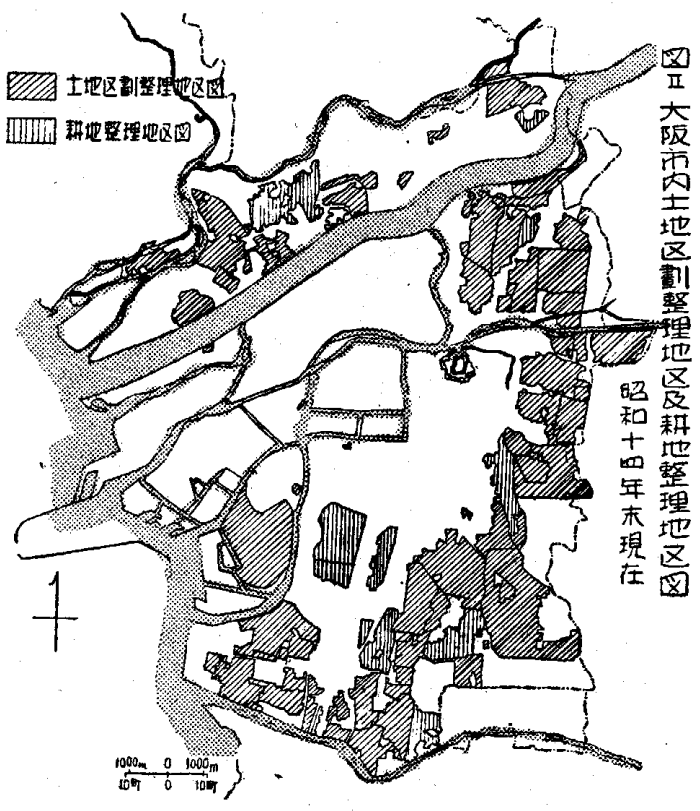

第 2 図
そなつて、爾後引続いて組合は結成された。

兹に注目されることは、これ等の組合設立に最も協力 したのは、最初のうちは前記の土地会社であつた。今迄 土地会社は土地の合併分筆をする際に、他人の土地の介 在で、理想の仕事を遂行し得ないので困却した。それが 区劃整理になると、法律の仳護で容易に目的を果すこと が出来るからであつた。

区劃整理はまことに順調であつて、

\begin{tabular}{|c|c|c|c|}
\hline 大正 & 15 年末 & 7 組合 & $1,437,741$ 理 \\
\hline 昭和 & 3 年 & $20 "$ (累計) & $3,394,889$ \\
\hline " & 5 年 & $38 "$ & $7,786,260$ \\
\hline " & 8 年 & $51 "$ & $9,871,502$ \\
\hline & 11 年 & $65 \prime$ & $11,214,434$ \\
\hline & 14 年 & $80 "$ & $13,402,040$ \\
\hline
\end{tabular}

これ等の進涉状沅は、初めの汇り出しは名古屋飞先を 越されていたが、終には組合数も総面積も名古屋を追い 越した。東京は両者滛か浪ばなかつた。この進渉に 最も力を籍したのは、大阪府建築課建築線係であつた。

所が年々区劃整理で龙大な建築教地が創造され、各組 合は自己の地区発展のために種々努力することになつた ので、これ等のことが図らずる、土地会社には致命的打 撃となつた。

土地会社は莫大な資本を㩲していたとはい光、区劃整 理はその建前上、大資本を必要としないから、土地会社 は資本で組合に対抗することは、意味がなかつた。一方 区劃整理は組合の数も多いが、その面積が土地会社と比 較した場合に、压倒的に大であつて、殆んど大厉の周辺 を取り巻いた。更に土地の需要者は今をで土地会社を相 当高く買つていたが、今度は組合地区内何処ででる得ら れることになつた。これらのことが土地会社の大きな競 走相手となつた。

以上の結果、市内よりも寍も電鉄沿線の土地会社が非 常な打撃を受けた。そして新らしい分僙地の計画は就ろ か今手持の土地の処分にも困難を感ずることになつた。

斯して、新田の跡を開発して分割賃貸するるのを除い て太平洋戦争に突入前に䀣に土地会社は、都市計画と経 済界に華々しい成果を残しつつも调落を余儀なくされた のである。

\section{6. 今日の問題}

都市計画の暗黒時代に、光明を差し伸べたのは、土地 会社であつた。その後土地区劃整理がこれに代つて登場 した。然るに太平洋戦争は区劃整理を一頓挫せしめたの であるが、更泈戦後の農地法が住宅地の計画的開発を 全く困難なるのにして仕舞つた。それで今また昔の暗黒 時代に逆転しょうとしている。これを如何に処置すべき か恃今日の都市計画の大きな問題である。本交はその解 決を考えるのについての一つの椤古である。 